BIBLIOTIKA : Jurnal Kajian Perpustakaan dan Informasi

Volume 2 Nomor 1, 2018

Journal homepage : http://journal2.um.ac.id/index.php/bibliotika

\title{
Hubungan Kebutuhan Informasi Mahasiswa Program Studi Ilmu Perpustakaan dalam Penyelesaian Skripsi dengan Ketersediaan Koleksi
}

\author{
Hanafi Almas*, Kusubakti Andajani, Zeni Istiqomah \\ Universitas Negeri Malang, Indonesia
}

\begin{tabular}{|c|c|}
\hline A R T I C LE I N F O & A B S T R A C T \\
\hline $\begin{array}{l}\text { Keyword: } \\
\text { kebutuhan informasi, } \\
\text { penyelesaian skripsi, } \\
\text { ketersediaan koleksi }\end{array}$ & $\begin{array}{l}\text { Tujuan penelitian ini adalah untuk mengetahui hubungan kebutuhan informasi mahasiswa } \\
\text { program studi ilmu perpustakaan dalam penyelesaian skripsi dengan ketersediaan koleksi } \\
\text { di Perpustakaan Pusat Universitas Negeri Malang. Penelitian ini menggunakan pendekatan } \\
\text { kuantitatif dengan jenis penelitian korelasional. hasil penelitian ini menunjukkan terdapat } \\
\text { hubungan yang positif antara kebutuhan informasi mahasiswa Program Studi Ilmu } \\
\text { Perpustakaan dalam penyelesaian skripsi dengan ketersediaan koleksi di Perpustakan } \\
\text { Pusat Universitas Negeri Malang sebesar 0,558 yang termasuk kategori sedang. }\end{array}$ \\
\hline
\end{tabular}

\section{PENDAHULUAN}

Penyelenggaraan perpustakaan dalam lembaga pendidikan sebagai pusat sumber informasi dan belajar (Almas, 2017). Perpustakaan perguruan tinggi menyediakan sumber informasi yang dapat menunjang kegiatan pembelajaran bagi setiap civitas akademika yang ada di lingkungan perguruan tinggi. Keberadaan perpustakaan juga memegang peranan penting dalam membantu tercapainya tujuan dari lembaga induknya. Tujuan perpustakaan perguruan tinggi menurut Istiana (2014:5) untuk menunjang kegiatan Tri Dharma Perguruan Tinggi yaitu pendidikan, penelitian, dan pengabdian masyarakat. Perpustakaan perguruan tinggi menyediakan sumber informasi yang dapat dimanfaatkan oleh mahasiswa dan dosen dalam memenuhi kebutuhan informasinya. Secara umum kebutuhan informasi adalah sesuatu yang harus dimiliki atas dasar kepentingan interpersonal. Menurut Ishak (2006:91) kebutuhan informasi timbul ketika pengetahuan yang dimiliki seseorang kurang dari yang dibutuhkan, sehingga mendorong untuk mencari informasi. Pada hakikatnya tidak ada perpustakaan yang mampu memenuhi segala kebutuhan informasi pemustaka, hal tersebut juga dipaparkan oleh Rahmah (2015:8) tidak mungkin bagi sebuah perpustakaan dapat memenuhi semua kebutuhan informasi pemustakanya. Melihat kondisi tersebut, kembali pada perpustakaan perguruan tinggi dengan menyediakan sumber informasi yang sesuai dengan program yang dijalankan oleh lembaga yang menaunginya. Kebutuhan mahasiswa di lingkungan perguruan tinggi cukup beragam dan bermacammacam. Salah satu hal yang harus dipenuhi oleh mahasiswa dalam rangka proses penyelesaian masa studi di perguruan tinggi adalah dengan menyelesaikan karya ilmiah berupa skripsi. Pada proses penyelesaian skripsi, mahasiswa akan berkaitan dengan bagaimana ketersediaan sumber informasi yang tersedia di perpustakaan perguruan tinggi dapat mendukung mahasiswa dalam proses penyelesaian skripsi. Sumber informasi yang tersedia di perpustakaan perguruan tinggi yang dapat dimanfaatkan oleh mahasiswa dalam pemenuhan kebutuhan informasinya adalah koleksi perpustakaan.

Perpustakaan Pusat Universitas Negeri Malang (UM) menyediakan sumber informasi dan ilmu pengetahuan yang dapat dimanfaatkan oleh mahasiswa dan dosen dalam pemenuhan kebutuhan informasi dan ilmu pengetahuan. Perpustakaan Pusat UM juga berperan dalam mendukung kegiatan penelitian. Berdasarkan hasil observasi awal yang dilakukan, jumlah koleksi yang tersedia di Perpustakaan

\footnotetext{
" Corresponding author.

E-mail addresses: hanafialmas23@gmail.com (Hanafi Almas)
}

ISSN : 2579-3802 (Online) - BIBLIOTIKA : Jurnal Kajian Perpustakaan dan Informasi is licensed under Creative Commons AttributionShareAlike 4.0 International License (http://creativecommons.org/licenses/BY/4.0/).

63 | BIBLIOTIKA : Jurnal Kajian Perpustakaan dan Informasi 
Unviersitas Negeri Malang pada tahun 2017 sebanyak 58.322 dengan jumlah eksemplar sebanyak 139.728. Selain jumlah tersebut, Perpustakaan Pusat UM juga melanggan e-journal diantaranya Spinger Link, Cambridge, ERIC, Wiley Online Library, Emerald, Sage Journal, dan Oxford. Terdapat koleksi yang berhubungan dengan Program Studi Ilmu Perpustakaan sebanyak 552 judul dan 1171 eksemplar. Sejauh ini Perpustakaan Pusat UM selalu dimanfaatkan dalam kegiatan akademik, salah satunya sebagai bahan rujukan dalam penyelesaian skripsi mahasiswa.Sebagai sumber rujukan dalam penyelesaian skripsi mahasiswa, Perpustakaan Pusat UM juga menyediakan koleksi karya ilmiah. Karya ilmiah berupa skripsi di bidang ilmu perpustakaan yang tersedia di Perpustakaan Pusat UM pada tahun 2017 sebanyak 24 judul skripsi. Program Studi Ilmu Perpustakaan Universitas Negeri Malang. Wawancara awal dilakukan pada mahasiswa Program Studi Ilmu Perpustakaan yang telah memprogram skripsi, terkait bagaimana kebutuhan informasi dalam penyelesaian skripsi dengan melihat kondisi ketersediaan koleksi yang ada di Perpustakaan Pusat UM. Hasil wawancara tersebut menunjukkan sebagaian besar buku dan jurnal sangat dibutuhkan dalam memenuhi kebutuhan informasi mereka, namun ketersediaannya di Perpustakaan Pusat UM masih belum memenuhi kebutuhan informasi mereka.

Hasil penelitian yang dilakukan oleh Koto (2007:45) menujukkan kebutuhan informasi peneliti dapat diukur dengan tiga aspek yaitu jenis informasi, sumber perolehan informasi dan format informasi yang diperlukan. Aspek jenis informasi yang diperlukan dapat berupa buku, jurnal dan laporan penelitian. Aspek sumber perolehan informasi tersebut dapat melalui perpustakaan, internet dan koleksi individu. Aspek format informasi yang diperlukan berupa bentuk tercetak dan elektronik. Hasil penelitian yang dilakukan oleh Sumarsih (2017:4) menjabarkan tahun terbitan sumber informasi yang dibutuhkan oleh peneliti dapat berupa terbita terbaru dengan rentang waktu lima tahun terakhir dan terbitan lama lebih dari lima tahun terakhir. Pendit (dalam Zulaika, 2007:50) menjabarkan, interdisiplineritas ilmu perpustakaan yang dibutuhkan peneliti meliputi informasi dalam bidang statistik, manajemen dan teknologi informasi. Ketersediaan koleksi di perpustakaan perguruan tinggi dijabarkan oleh Rahmah (2015:8) ketersediaan koleksi perpustakaan harus didasari , (a) kerelevanannya dengan program pendidikan, pengajaran, penelitian dan pengabdian masyarakat; (b) kemutakhiran sesusi dengan perkembangan ilmu pengetahuan; (c) kelengkapan dan keterkaitan bidang ilmu; (d) jenis koleksi yang disesuaikan dengan pemustakanya.

Penelitian terdahulu terkait dengan penelitian ini yakni, Identifikasi Kebutuhan Informasi Peneliti dalam Menunjang Kegiatan penelitian pada Pusat Penelitian Kelapa Sawit Sumatera Utara diteliti oleh Koto (2007) dengan hasil penelitian kebutuhan informasi peneliti meliputi enam kategori berupa kebutuhan informasi, jenis koleksi, format informasi, sumber informasi, yang dibutuhkan dalam menunjang kegiatan penelitian. Kemudian yang terbaru Kebutuhan dan Perilaku Pencarian Informasi Staf Pengajar Politeknik Negeri Semarang dalam Melaksanakan Kegiatan Penelitian diteliti oleh Sumarsih (2017) dengan hasil penelitian sumber informasi yang dibutuhkan, tahun publikasi informasi, lokasi perolehan informasi, dan pola pencarian informasi dalam melaksanakan kegiatan penelitian. Pentingnya penelitian ini dilakukan, untuk mengetahui bagaimana kebutuhan informasi mahasiswa Program Studi Perpustakaan dalam penyelesaian skripsi dengan ketersediaan koleksi di Perpustakaan Pusat UM

\section{METODE PENELITIAN}

Penelitian ini menggunakan pendekatan kuantitatif dengan jenis penelitian deskriptif korelasional yang bertujuan untuk mencari hubungan antara kebutuhan informasi mahasiswa Program Studi Ilmu Perpustakaan dalam penyelesaian skripsi dengan ketersediaan koleksi di Perpustakaan Pusat Universitas Negeri Malang. Subjek penelitian ini mahasiswa Program Studi Ilmu Perpustakaan yang telah memprogram skripsi pada tahun ajaran 2017/2018. Sedangkan objek penelitian ini adalah Perpustakaan Pusat Universitas Negeri Malang.

Populasi penelitian ini adalah mahasiswa S1 Program Studi Ilmu Perpustakaan yang telah memprogram skripsi dan koleksi di Perpustakaan Pusat Universitas Negeri Malang baik secara langsung atau tidak langsung yang berhubungan dengan Program Studi Ilmu Perpustakaan. Pengambilan sampel dengan menggunakan sampling jenuh dengan jumlah sampel sebesar 50 responden. Sedangkan metodenya melalui sampel random sederhana. Metode ini dipilih karena sampel dalam penelitian ini bersifat homogen, yaitu Mahasiswa Program Studi Ilmu Perpustakaan yang sedang dalam proses penyelesaian skripsi. Teknik pengumpulan data ada penelitian ini menggunakan angket dan wawancara. Skala pengukuran data menggunakan skala likert dengan empat pilihan jawaban. Wujud data pada penelitian ini berupa skor hasil pengisian angket oleh responden dan data hasil wawancara responden.

Analisis data pada penelitian ini menggunakan statistik deskriptif, uji prasyarat dan uji hipotesis. Analisis data dengan menggunakan bantuan program IBM SPSS Statistic versi 24. Adapun langkahlangkah dalam analisis deskriptif adalah menentukan mean, menentukan standar deviasi, menentukan 
panjang kelas interval. Uji prasyarat yang digunakan dalam penelitian ini adalah uji normalitas data dan uji linearitas data. Uji normalitas digunakan untuk mengetahui apakah kedua variabel berdistribusi normal atau tidak. Uji linearitas digunakan untuk menguji hubungan antara variabel dependent dan variabel independent tersebut linier atau tidak. Uji normalitas pada penelitian ini menggunakan pengujian Kolmogrov-Smirnov Test, untuk uji linearitas menggunakan teknik analisis satu jalur One Way Anova (Analysis of Variance). Teknik analisis yang digunakan untuk menganalisis korelasi adalah analisis korelasi Product Moment Pearson.

\section{HASIL PENELITIAN}

Kebutuhan Informasi Mahasiswa dalam Penyelesaian Skripsi

Data hasil penelitian diperoleh dari penyebaran angket kepada responden sejumlah 50 mahasiswa. Data yang terkumpul adalah data mengenai kebutuhan informasi mahasiswa dalam penyelesaian skripsi, dan data ketersediaan koleksi di Perpustakaan Pusat Universitas Negeri Malang. Pada variabel kebutuhan informasi terdiri dari 5 sub variabel, yaitu jenis informasi yang dimanfaatkan, sumber perolehan informasi, tahun terbitan sumber informasi, format sumber informasi, dan interdisiplineritas ilmu perpustakaan dan informasi. Variabel ini terdiri dari 14 pernyataan. Berdasarkan data yang terkumpul dari 50 responden, nilai minimum adalah 16 dan nilai maksimum adalah 54 . Kelas interval pada variabel kebutuhan informasi dapat diketahui dengan perhitungan nilai maksimum dikurangi dengan nilai minimum dibagi dengan banyak kelas interval yakni 4 yang hasilnya 9,5 dan dibulatkan menjadi 10. Hasil analisis diperoleh data berupa mean 42.88, median 43, modus 46 ,dan standar deviasi sebesar 7,75. Berikut adalah frekuensi variabel kebutuhan informasi mahasiswa.

Tabel 4.3 Distribusi Frekuensi Kebutuhan Informasi

\begin{tabular}{cccc}
\hline Kriteria Pengelompokkan & Kategori & Frekuensi & Presentase \\
\cline { 2 - 4 } & & & \\
Nilai $>51$ & Tinggi & 5 & $10 \%$ \\
$35<$ Nilai $<51$ & Sedang. & 41 & $82 \%$ \\
Nilai $<35$ & Rendah & 4 & $8 \%$ \\
Jumlah & & 50 & $100 \%$ \\
\hline
\end{tabular}

Berdasarkan pada tabel 4.3 tentang distribusi frekuensi kebutuhan informasi mahasiswa dari 50 responden, sebanyak 5 responden memiliki kebutuhan informasi dalam kategori tinggi, sebanyak 41 responden memiliki kebutuhan informasi dalam kategori sedang, dan 4 responden memiliki kebutuhan informasi dalam kategori rendah. Dapat disimpulkan bahwa kebutuhan informasi mahasiswa sebagian besar dalam penyelesaian skripsi Program Studi Ilmu Perpustakaan Universitas Negeri Malang termasuk dalam kategori sedang, dengan jumlah 41 responden. Hasil wawancara responden menujukkan, kebutuhan informasi mahasiswa Program Studi Ilmu Perpustakaan dalam penyelesaian skripsi secara garis besar memanfaatkan koleksi yang tersedia di Perpustkaan Pusat Universitas Negeri Malang. Sumber informasi yang dibutuhkan mahasiswa namun tidak tersedia di Perpustakaan Pusat Universitas Negeri Malang, sebagian besar memenuhi kebutuhan informasinya dengan memanfaatkan sumber informasi melalui internet.

\section{Ketersediaan Koleksi Perpustakaan}

Variabel ketersediaan koleksi di Perpustakaan Pusat Universitas Negeri Malang terdiri dari lima indikator, yaitu kemutakhiran koleksi, relevansi koleksi, jenis koleksi, dan kelengkapan koleksi. Variabel ketersediaan koleksi terdiri dari 12 pernyataan. Berdasarkan data yang terkumpul dari 50 responden, nilai minimum adalah 18 dan nilai maksimum adalah 47. Kelas interval pada variabel ketersediaan koleksi dapat diketahui dengan perhitungan nilai maksimum dikurangi dengan nilai minimum dibagi dengan banyak kelas interval yakni 4 yang hasilnya 7.25 dan dibulatkan menjadi 7. Adapun hasil analisis yang diperoleh data berupa mean 34.54, modus 38, dan standar deviasi sebesar 6.40. Berikut dijabarkan pada tabel 4.5 di bawah ini

Tabel 4.5 Frekuensi Variabel Ketersediaan Koleksi

\begin{tabular}{ccccc}
\hline Kriteria Pengelompokkan & & Kategori & Frekuensi & Persentase \\
\cline { 2 - 3 } Nilai $>41$ & Tinggi & 7 & $14 \%$ \\
$29<$ Nilai $<41$ & Sedang & 32 & $64 \%$ \\
Nilai $<29$ & Rendah & 11 & $22 \%$ \\
Jumlah & & 50 & $100 \%$ \\
\hline
\end{tabular}


Berdasarkan tabel 4.5 tentang frekuensi dan distribusi frekuensi variabel ketersediaan koleksi dari 50 responden, sebanyak 7 responden menyatakan ketersediaan koleksi di Perpustakaan Pusat Universitas Negeri Malang termasuk dalam kategori tinggi, kemudian 32 responden menyatakan ketersediaan koleksi di Perpustakaan Pusat Universitas Negeri Malang termasuk dalam kategori sedang, dan 11 responden menyatakan ketersediaan koleksi di Perpustakaan Pusat Universitas Negeri Malang termasuk dalam kategori rendah. Dapat disimpulkan sebagian besar responden menyatakan ketersediaan koleksi di Perpustakaan Pusat Universitas Negeri Malang termasuk dalam kategori sedang, dengan jumlah 32 responden. Hasil wawancara responden menunjukkan, ketersediaan koleksi di Perpustakaan Pusat Universitas Negeri Malang secara garis besar sudah memenuhi kebutuhan informasi mahasiswa dalam penyelesaian skripsi. Tersedianya koleksi bidang penelitian seperti bukubuku metode penelitian dan hasil karya ilmiah tentunya dapat menunjang mahasiswa dalam melaksanakan kegiatan penelitian. Jenis koleksi yang dianggap oleh sebagian besar responden masih belum memenuhi kebutuhan informasinya adalah e-journal dan e-book dibidang ilmu perpustakaan.

\section{Uji Asumsi Klasik}

Uji hipotesis dapat dilakukan apabila sebaran data setiap variable berdistribusi dengan normal, dan hubungan antar kedua variabel bersifat linier. Pemenuhan syarat tersebut dengan dilakukan uji normalitas dan uji linearitas. Uji normalitas yang digunakan dengan menggunakan pengujian Kolmogrov-Smirnov Test, jika nilai signifikansi lebih dari 0,05 $(\mathrm{p}>0,05)$ maka data tersebut berdistribusi normal. Berdasarkan hasil uji normalitas pada penelitian ini dapat diketahui nilai signifikansi 0,200 >0,05 maka dapat disimpulkan nilai residual berdistribusi normal. Uji linearitas dengan menggunakan teknik analisis satu jalur One Way Anova (Analysis of Variance). Jika nilai signifikansi $\mathrm{F}>0,05$ (sig >0,05) maka hubungan antar kedua variabel tersebut linier. Hasil dari uji linearitas pada penelitian ini menunjukkan nilai Sig. deviation from linearity sebesar 0,973>0,05 dan nilai F 0,421 > 0,05 maka dapat disimpulkan bahwa terdapat hubungan yang linier antara kebutuhan informasi mahasiswa dengan ketersediaan koleksi di perpustakaan.

\section{Hubungan Kebutuhan Informasi Mahasiswa dengan Ketersediaan Koleksi}

Uji korelasi pada penelitian ini menggunakan analisis korelasi Product Moment Pearson. Hasil uji korelasi kebutuhan informasi mahasiswa dalam penyelesaian skripsi dengan ketersediaan koleksi bahan pustaka di Perpustakaan Pusat Universitas Negeri Malang. Hasil uji korelasi pada penelitian ini terdapat dua variabel yakni variabel kebutuhan informasi mahasiswa dalam penyelesaian skripsi (X) dengan ketersediaan koleksi bahan pustaka di Perpustakaan Pusat Universitas Negeri Malang (Y). Dapat diketahui bahwa dengan taraf kesalahan sebesar 0,05 diperoleh koefisien signifikansi sebesar 0,000 . Sehingga ditolak karena nilai koefisien signifikansi kurang dari 0,05. Maka dapat disimpulkan bahwa terhadap hubungan yang positif dan signifikan antara kebutuhan informasi mahasiswa Program Studi Ilmu Perpustakaan dalam penyelesaian skripsi dengan ketersediaan koleksi bahan pustaka di Perpustakaan Pusat Universitas Negeri Malang. Berdasarkan pedoman interpretasi koefisien korelasi pada tabel 3.5 nilai korelasi 0,558 termasuk dalam kategori sedang.

\section{PEMBAHASAN}

\section{Kajian Kebutuhan Informasi Mahasiswa dalam Penyelesaian Skripsi}

Berdasarkan hasil analisis dapat dinyatakan bahwa kebutuhan informasi mahasiswa dalam penyelesaian skripsi termasuk dalam kategori sedang. Hal ini dapat diketahui berdasarkan hasil analisis dari 50 responden terdapat 5 mahasiswa atau sebesar $10 \%$ yang memiliki tingkat kebutuhan informasi dengan kategori tinggi, 41 mahasiswa atau sebesar $82 \%$ yang memiliki tingkat kebutuhan informasi dengan kategori sedang, dan 4 mahasiswa atau sebesar $8 \%$ yang memiliki tingkat kebutuhan informasi dengan kategori rendah. Hasil analisis variabel kebutuhan informasi mahasiswa dalam penyelesaian skripsi menujukkan nilai mean atau rata rata-rata skor hasil pengisian angket sebesar 42,8 . Kebutuhan informasi mahasiswa dalam penyelesaian skripsi diukur dengan lima sub variabel yaitu, jenis informasi yang dimanfaatkan, sumber perolehan informasi, tahun terbitan sumber informasi, format sumber informasi dan interdisiplineritas sumber informasi .

Pada sub variabel jenis informasi yang dimanfaatkan mahasiswa, terdapat tiga indikator yaitu buku, jurnal dan hasil penelitian. Berdasarkan tiga indikator pada sub variabel jenis informasi yang dimanfaatkan mahasiswa dalam penyelesaian skripsi Program Studi Ilmu Perpustakaan Universitas Negeri Malang, indikator yang paling dominan adalah buku. Sebanyak 92 \% mahasiswa memanfaatkan jenis informasi melalui buku, sebanyak 90 \% mahasiswa juga memanfaatkan jenis informasi melalui jurnal dan hasil penelitian sebelumnya. Jenis informasi tersebut dimanfaatkan mahasiswa karena 
koleksi tersebut akurat, terpercaya dan dapat digunakan sebagai bahan rujukan dalam penyelesaian skripsi. Pemanfaatan jenis informasi berupa buku sesuai dengan pendapat Sumarsih (2017:6) buku merupakan koleksi atau sumber informasi primer yang selalu digunakan atau dibutuhkan oleh peneliti, sebagian besar informasi dalam bentuk buku ini dibutuhkan peneliti untuk mengetahui perkembangan informasi sesuai dengan bidangnya. Pemanfaatan jenis informasi berupa jurnal sesuai dengan pendapat Rusydi (2014:200) jurnal merupakan salah satu literatur terbitan berseri yang bersifat relevan serta dapat menunjang seorang peneliti dalam kegiatan penelitiannya. Pemanfaatan hasil penelitian sesuai dengan pendapat Ishartati (2008:18) hasil penelitian sebelumnya meliputi beberapa aspek yang dapat dipergunakan pemustaka sebagai bahan acuan dan bahan rujukan penulisan karya ilmiah.

Pada sub variabel sumber perolehan informasi dengan empat indikator yang meliputi, perpustakaan, internet, lembaga informasi lain dan koleksi individu. Berdsarkan empat indikator pada sub variabel sumber perolehan informasi yang dimanfaatkan mahasiswa dalam penyelesaian skripsi Program Studi Ilmu Perpustakaan Universitas Negeri Malang. Sebanyak 88 \% mahasiswa memanfaatkan perpustakaan dan internet sebagai sumber perolehan informasi, 66\% mahasiswa memanfaatkan sumber informasi lain sebagai sumber perolehan informasi, dan sebesar $54 \%$ mahasiswa memanfaatkan koleksi individu sebagai sumber perolehan informasi. Sumber perolehan informasi melalui internet sedikit lebih dominan dari pada perpustakaan. Berdasarkan hasil analisis angket responden, sumber perolehan informasi melalui internet dilakukan sebagian besar mahasiswa karena kemudahan akses dimana saja dengan menggunakan perangkat komunikasi yang dilimiliki mahasiswa. Hal tersebut sesuai dengan pendapat Hasugian (2008:13) internet memungkinkan pengguna mengakses informasi dan pelayanan dari mana saja dan kapan saja dengan menggunakan peralatan pilihan mereka. Sumber informasi melalui internet dimanfaatkan sebagian besar mahasiswa jika sumber informasi yang dibutuhkannya tidak tersedia di perpustakaan Pusat UM.

Pada sub variabel tahun terbitan sumber informasi dengan dua indikator yang meliputi, terbitan terbaru dan terbitan lama. Berdsarkan dua indikator pada sub variabel tahun terbitan sumber informasi yang dimanfaatkan mahasiswa dalam penyelesaian skripsi Program Studi Ilmu Perpustakaan Universitas Negeri Malang. Indikator yang dominan adalah pemanfaatan sumber informasi tahun terbitan terbaru dengan responden sebanyak $82 \%$ mahasiswa, pemanfaatan sumber informasi dengan tahun terbitan lama dengan responden sebanyak $78 \%$ mahasiswa. Kedua jenis terbitan sumber informasi tersebut sama-sama digunakan oleh sebagian besar mahasiswa, dapat diketahui sebelumnya sumber informasi dengan tahun terbitan lama tetap diperlukan dan dapat diperkuat dengan sumber informasi dengan tahun terbitan terbaru sebagai rujukan dalam penyelesaian skripsi. Hal tersebut sesuai dengan pendapat Sumarsih (2017:6) penggunaan tahun publikasi sumber informasi untuk mendukung kegiatan penelitian cukup beragam dan tidak terbatas tahunnya, karena melihat dari tema, fungsi dari sumber informasi tersbut.

Pada sub variabel format sumber informasi terdapat dua indikator yang meliputi, informasi dalam bentuk tercetak dan informasi dalam bentuk elektronik. Pemanfaatan sumber informasi dalam format tercetak dan elektronik sama-sama dibutuhkan oleh sebagian besar mahasiswa. Pemanfaatan kedua format informasi tersebut dikarenakan melihat kondisi ketersediaan sumber informasi yang ada di perpustakaan Pusat UM. Hal tersebut sesuai dengan pendapat Koto (2007:45) informasi dalam berbagai bentuk format dibutuhkan peneliti dalam memperoleh data yang berkaitan dengan penelitian, untuk mendapatkan informasi yang berkualitas erat aitannya dengan penyajian bentuk informasi dalam bentuk tercetak dan elekronik yang keduanya sama-sama dibutuhkan oleh peneliti.

Pada sub variabel interdisiplineritas ilmu perpustakaan dan informasi terdapat indikator yang meliputi bidang ilmu statistik, bidang manajemen, dan teknologi informasi. Berdasarkan tiga indikator pada sub variabel interdisiplineritas ilmu perpustakaan dan informasi, indikator yang dominan adalah pada bidang teknologi informasi. Hal tersebut sesuai dengan pendapat Zulaika (2007:51) ilmu perpustakaan dan informasi berhubungan dengan bidang teknologi informasi, ilmu perpustakaan juga sebagai partisipan aktif dalam evolusi masyarakat informasi dalam bidang teknologi informasi. Selain itu, kemajuan perpustakaan juga berkaitan dengan perkembangan teknologi informasi sebagaimana pendapat Rifai (tanpa tahun:24) perpustakaan sebagai salah satu lembaga yang menyediakan jasa informasi bagi pemustaka yang memerlukan teknologi informasi untuk memberikan pelayanan yang lebih baik.

Berdasarkan paparan hasil analisis pada variabel kebutuhan informasi mahasiswa Program Studi Ilmu Perpustakaan Universitas Negeri Malang dalam penyelesaian skripsi dapat disimpulkan. Jenis informasi yang dibutuhkan sebagian besar mahasiswa pada jenis koleksi buku, jurnal, dan hasil penelitian sebelumnya. Sumber perolehan informasi mahasiswa sebagian besar dengan memanfaatkan sumber informasi melalui internet dan perpustakaan. Tahun terbitan sumber informasi yang dibutuhkan 
mahasiswa, sebagian besar memanfaatkan terbitan informasi terbaru dan terbitan lama sebagai rujukan dalam penyelesaian skripsi. Format sumber informasi yang dibutuhkan sebagian besar mahasiswa format informasi dalam bentuk tercetak dan elektronik yang tersedia di Perpustakaan Pusat UM. Interdisiplineritas ilmu perpustakaan dan informasi yang dibutuhkan mahasiswa dalam penyelesaian skripsi adalah bidang teknologi informasi dan statistik, sebagai rujukan rujukan metodologi penelitian mahasiswa dan pengembangan teknologi informasi di perpustakaan.

\section{Kajian Ketersediaan Koleksi Perpustakaan}

Berdasarkan hasil analisis dapat dinyatakan bahwa, ketersediaan koleksi di Perpustakaan Pusat Universitas Negeri Malang termasuk dalam kategori sedang. Hal ini berdasarkan hasil analisis dari 50 responden terdapat 7 mahasiswa atau sebesar $14 \%$ yang menyatakan ketersediaan koleksi di Perpustakaan Pusat Universitas Negeri Malang termasuk dalam kategori tinggi, 32 mahasiswa atau sebesar $64 \%$ yang menyatakan ketersediaan koleksi perpustakaan termasuk dalam kategori sedang, dan 11 mahasiswa atau sebesar 22 \% menyatakan ketersediaan koleksi perpustakaan termasuk dalam kategori rendah. Hasil analisis variabel ketersediaan koleksi di Perpustakaan Pusat UM menujukkan nilai mean atau rata rata-rata skor hasil pengisian angket sebesar 34,5. Berdasarkan hasil analisis pada variabel ketersediaan koleksi, terdapat satu sub variabel koleksi yang diadakan Perpustakaan Pusat UM dan terdapat empat indikator.

Indikator yang pertama pada sub variabel koleksi yang diadakan Perpustakaan Pusat UM dilihat dari kemutakhiran koleksi (Hanafiyah, 2018). Kemampuan literasi diartikan sebagai keterampilan membaca, menulis, dan berpikir. Literasi merupakan kemampuan penting yang harus dimiliki peserta didik untuk menguasai berbagai mata pelajaran. Sebagaimana yang dijelaskan dalam kurikulum 2013 bahwa pelajaran Bahasa Indonesia merupakan penghela pengetahuan, kemampuan anak membaca dan menulis dalam pelajaran Bahasa Indonesia sangat memengaruhi keberhasilan dalam menguasai mata pelajaran lain. Penerapan literasi lintas kurikulum dalam pembelajaran bahasa Indonesia di sekolah menengah kejuruan dapat diintegrasikan dengan mata pelajaran Muatan Nasional (A), Muatan Kewilayahan (B), Dasar Bidang Keahlian (C1), Dasar Program Keahlian (C2), dan Kompetensi Keahlian (C3). Hasil analisis kemutakhiran koleksi dengan tahun terbitan terbaru yang tersedia di Perpustakan Pusat UM dengan persentase sebesar 76 \%. Hasil analisis kemutakhiran koleksi dengan mengikuti perkembangan informasi saat ini yang tersedia di Perpustakaan Pusat UM dengan persentase sebesar $66 \%$. Hasil wawancara responden terkait aspek kemutakhiran koleksi yang tersedia di Perpustakaan Pusat UM sudah cukup mutakhir. Kemutakhiran koleksi yang tersedia di perpustakaan tentu diperlukan oleh peneliti dalam mendukung kegiatan penelitian karena sesuai dengan perkembangan ilmu pengetahuan. Hal tersebut sesuai dengan pendapat Darmono (2001:49) kemutakhiran sumber informasi di perpustakaan harus diupayakan sesuai dengan perkembangan ilmu pengetahuan, kemutakhiran dapat dilihat pada bahan pustaka dengan tahun terbit terbaru.

Indikator yang kedua pada sub variabel koleksi yang diadakan Perpustakaan Pusat UM adalah relevansi koleksi. Hasil analisis relevansi koleksi dengan kurikulum yang berlaku dengan jumlah persentase sebesar $72 \%$. Hasil analisis relevansi koleksi dengan bidang penelitian saat ini dengan jumlah persentase sebesar $62 \%$. Hasil wawancara responden terkait relevansi koleksi yang tersedia di Perpustakaan Pusat UM belum sepenuhnya relevan. Aspek relevansi koleksi yang tersedia di perpustakaan harus sesuai dengan bidang dan lembaga yang menaungi perpustakaan tersebut. Hal tersebut sebagaimana pendapat Humairo (2015:7) koleksi perpustakaan harus relevan dengan program pendidikan, pengajaran, penelitian dan pengabdian masyarakat, tersedianya koleksi yang relevan dapat dimanfaatkan pemustaka dalam pemenuhan kebutuhan informasinya.

Indikator yang ketiga pada sub variabel koleksi yang diadakan Perpustakaan Pusat UM adalah jenis koleksi. Hasil analisis terkait dengan jenis koleksi yang tersedia di Perpustakaan Pusat UM, untuk ketersediaan koleksi buku bidang perpustakaan dengan jumlah persentase sebesar $82 \%$. Ketersediaan koleksi buku bidang penelitian dengan jumlah persentase sebesar $86 \%$. Ketersediaan koleksi hasil karya ilmiah berupa skripsi dan tugas akhir bidang ilmu perpustakaan dengan jumlah persentase sebesar $84 \%$. Ketersediaan koleksi jurnal bidang perpustakaan dengan jumlah persentase sebesar $70 \%$. Ketersediaan koleksi e-journal bidang ilmu perpustakaan dengan jumlah persentase sebesar $72 \%$. Ketersediaan koleksi e-book bidang ilmu perpustakaan dengan persentase sebesar $48 \%$.

Hasil wawancara responden terkait jenis koleksi di Perpustakaan Pusat UM yang dianggap masih kurang dan belum sepenuhnya memenuhi kebutuhan informasi mahasiswa dalam penyelesaian skripsi terdapat pada koleksi jurnal, e-journal dan e-book dibidang ilmu perpustakaan. Dapat diketahui sumber informasi pada jurnal dan e-book merupakan informasi yang bersifat relevan dalam mendukung kegiatan penelitian. Hal tersebut berdasarkan dengan pendapat Rusydi (2014:200) jurnal merupakan salah satu literatur terbitan berseri yang relevan, tersedianya akses literatur tersebut di perpustakaan 
baik berupa format tercetak dan format digital dapat menunjang kegiatan penelitian yang dilakukan oleh peneliti.

Indikator yang keempat pada sub variabel koleksi yang diadakan di Perpustakaan Pusat UM dilihat dari kelengkapan koleksi. Hasil analisis terkait dengan kelengkapan koleksi bidang ilmu perpustakaan di Perpustakaan Pusat UM dengan jumlah persentase sebesar $42 \%$. Hasil analisis koleksi bidang penelitian di Perpustakaan Pusat UM dengan jumlah persentase sebesar 78 \%. Hasil wawancara responden terkait kelengkapan koleksi yang tersedia di Perpustakaan Pusat UM menunjukkan kelengkapan koleksi di Perpustakaan Pusat UM bidang perpustakaan dan bidang penelitian sudah cukup lengkap. Kelengkapan koleksi yang tersedia di perpustakaan diharapkan dapat memenuhi kebutuhan informasi mahasiswa, salah satunya dalam kegiatan penelitian. Kebutuhan informasi mahasiswa sangat beragam dan berbedabeda, menanggapi hal tersebut agar perpustakaan perguruan tinggi harus menyediakan koleksi yang sesuai dengan lembaga, sebagaimana pendapat Humairo (2015:7) kelengkapan adalah aspek ketersediaan koleksi terkait dengan pemustaka di perpustakaan, sehingga perpustakaan perlu menyediakan koleksi meliputi bidang ilmu yang berkaitan dengan program pada lembaga yang dinaunginya.

Berdasarkan paparan hasil analisis pada variabel ketersediaan koleksi di Perpustakaan Pusat Universitas Negeri Malang dapat disimpulkan. Kemutakhiran koleksi yang tersedia di Perpustakaan Pusat UM sudah cukup mutakhir dan dapat dimanfaatkan manasiswa dalam penyelesaian skripsi. Relevansi koleksi yang tersedia di Perpustakaan Pusat UM belum sepenuhnya relevan untuk koleksi bidang ilmu perpustakaan karena terdapat beberapa koleksi buku baru, namun sebagian besar responden masih kesulitan dalam mendapatkan informasi yang dibutuhkannya. Jenis koleksi di Perpustakaan Pusat UM yang dirasa masih kurang dan belum memenuhi kebutuhan informasi mahasiswa, terletak pada koleksi e-journal dan e-book dikarenakan Perpustakaan Pusat UM tidak melanggan koleksi tersbut khusus di bidang ilmu Perpustakaan. Kelengkapan koleksi di Perpustakaan Pusat UM untuk bidang ilmu perpustakaan dan bidang penelitian sudah cukup lengkap. Kondisi kelengkapan koleksi bidang ilmu perpustakaan dan bidang penelitian di Perpustakaan Pusat UM dapat dimanfaatkan mahasiswa dalam penyelesaian skripsi. Pemanfaatkan koleksi tersebut karena tersedianya koleksi buku baru dan koleksi hasil karya ilmiah yang dapat mendukung kegiatan penelitian mahasiswa.

\section{Kajian Hubungan Kebutuhan Informasi Mahasiswa dengan Ketersediaan Koleksi}

Berdasarkan hasil analisis yang telah dilakukan dapat diketahui variable kebutuhan informasi mahasiswa dalam penyelesaian skripsi termasuk dalam kategori sedang, dengan jumlah 41 mahasiswa atau dengan persentase sebesar

81 \%. Hasil analisis variabel ketersediaan koleksi di Perpustakaan Pusat UM termasuk dalam kategori sedang dengan jumlah 32 mahasiswa atau dengan persentase sebesar $64 \%$ Berdasarkan hasil analisis korelasi dengan menggunakan product moment pearson, diperoleh $r$ sebesar 0,558 dan nilai koefisien signifikansi sebesar $0,000<0,05$. Berdasarkan pendapat yang dijelaskan oleh Arikunto (2010:318), koefisien nilai sebesar 0,558 termasuk dalam kategori sedang.

Berdasarkan hasil analisis korelasi variabel di atas, dapat diketahui terdapat hubungan yang positif antara kebutuhan informasi mahasiswa Program Studi Ilmu Perpustakaan dengan ketersediaan koleksi di Perpustakaan Pusat UM. Sebagian besar mahasiswa Program Studi Ilmu Perpustakaan memanfaatkan sumber informasi yang tersedia di Perpustakaan Pusat UM untuk memenuhi kebutuhan informasi dalam penyelesaian skripsi. Terdapat beberapa sumber informasi yang dibutuhkan mahasiswa, namun tidak tersedia di Perpustakaan Pusat UM membuat sebagian besar mahasiswa memanfaatkan sumber informasi melalui internet dalam pemenuhan kebutuhan informasinya. Pemanfaatan sumber informasi melalui perpustakaan oleh mahasiswa dalam mendukung penyelesaian skripsi tersebut tersebut sesuai dengan pendapat Arianto (2010:2) perpustakaan sebagai sumber literatur utama bagi seorang peneliti untuk mengikuti perkembangan bidang yang ditekuninya. Jika sumber informasi yang diperlukan mahasiswa tidak tersedia di Perpustakaan Pusat UM baik dalam format tercetak maupun elektronik, hal yang dilakukan mahasiswa untuk memenuhi kebutuhan informasinya dengan memanfaatkan sumber informasi melalui internet. Hal tersebut sesuai dengan pendapat Arianto (2010:3) tersedianya informasi di internet dan semakin canggihnya mesin pencari informasi membuat peneliti lebih cepat dalam mencari informasi yang diperlukannya. Kondisi ketersediaan koleksi di Perpustakaan Pusat UM yang masih belum mampu memenuhi kebutuhan informasi mahasiswa secara keseluruhan merupakan hal yang wajar. Hal tersebut sesuai dengan pendapat Rahmah (2015:8) tidak mungkin bagi sebuah perpustakaan dapat memenuhi semua kebutuhan informasi pemustakanya. Menanggapi perpustakaan yang tidak dapat memenuhi kebutuhan informasi pemustakanya, maka koleksi yang tersedia di Perpustakaan Pusat UM harus sesuai dengan lembaga dan program yang dijalankannya. Hal tersebut berdasarkan pendapat Humairo (2015:7) perpustakaan perlu menyediakan 
koleksi meliputi bidang ilmu yang berkaitan dengan program pada lembaga yang dinaunginya. Ketersediaan koleksi pada Perpustakan Pusat UM yang sesuai dengan program dan lembaga tersebut, diharapkan secara garis besar kebutuhan informasi mahasiswa dalam penyelesaian skripsi dapat terpenuhi.

Ketersediaan koleksi yang ada di perpustakaan perguruan tinggi diharapkan dapat membantu pemenuhan kebutuhan informasi mahasiswa yang salah satunya untuk menunjang kegiatan penelitian. Pentingnya ketersediaan koleksi di perpustakaan untuk kegiatan penelitian sesuai dengan hasil penelitian sebelumnya yang dilakukan di Perpustakaan Universitas Indonesia yang diungkapkan oleh Ishak (2006:100) hasil dari penelitian tersebut dapat diketahui mahasiswa PPDS FK-UI angkatan 2004 dalam memenuhi tugas journal reading membutuhkan jenis koleksi di perpustakaan yang meliputi, buku, laporan penelitian, tesis, disertasi, dan jurnal ilmiah khususnya terbitan luar negeri dalam format elektronik. Penggunaan jurnal elektronik atau biasa disebut dengan e-journal untuk kegiatan penelitian didukung dengan pendapat Istiana (2014:29) e-journal memiliki kandungan informasi yang terbaru dan mutakhir, dan informasi yang dimuat dalam e-journal terpercaya maka sangat sesuai dengan kebutuhan para akademisi di perguruan tinggi sebagai pusat pengembangan penelitian dan ilmu pengetahuan.

Pentingnya ketersediaan koleksi karya ilmiah di perpustakaan perguruan tinggi juga sesuai dengan hasil penelitian yang dilakukan di Perpustakaan Fakultas Ilmu Budaya Universitas Diponegoro Semarang yang diungkapkan oleh Ilmiyah (2013:7) hasil dari penelitian tersebut dapat diketahui bahwa pemanfaatan koleksi local content berpengaruh dalam kegiatan penelitian mahasiswa yang sedang mengerjakan skripsi atau tugas akhir, kemudian koleksi local content juga berpengaruh bahan referensi, sumber informasi sekunder, panduan penulisan skripsi dan inspirasi dalam menentukan judul skripsi, serta bahan penelitian sebelumnya oleh mahasiswa. Penelitian selanjutnya dilakukan oleh Sumarsih (2017:4) hasil penelitian tersebut dapat diketahui bahwa, sumber informasi yang digunakan oleh sebagian besar staf pengajar untuk memenuhi kebutuhan informasi dalam melakukan kegiatan penelitian meliputi buku, jurnal, majalah, tugas akhir, skripsi, tesis, disertasi, laporan penelitian, yang sebagian besar merupakan koleksi yang tersedia di Perpustakaan Politeknik Negeri Semarang

\section{KESIMPULAN}

Hasil analisis kebutuhan informasi mahasiswa Program Studi Ilmu Perpustakaan dalam penyelesaian skripsi termasuk dalam kategori sedang. Hal tersebut dapat diketahui, sebagian besar mahasiswa memenuhi kebutuhan informasinya dalam penyelesaian skripsi dengan memanfaatkan koleksi yang tersedia di Perpustakaan Pusat UM. Sumber informasi yang dibutuhkan mahasiswa, namun tidak tersedia di Perpustakaan Pusat UM sebagian besar mahasiswa memenuhi kebutuhan informasinya melalui internet dan lembaga informasi lain.

Hasil analisis ketersediaan koleksi di Perpustakaan Pusat UM termasuk dalam kategori sedang. Hal tersebut dapat diketahui, kemutakhiran koleksi yang tersedia di Perpustakaan Pusat UM sudah cukup mutakhir. Koleksi yang tersedia belum sepenuhnya relevan karena sebagian besar responden masih kesulitan dalam mendapatkan informasi yang dibutuhkannya.

Terdapat hubungan yang positif dan signifikan antara variabel kebutuhan informasi mahasiswa Program Studi Ilmu Perpustakaan dengan ketersediaan koleksi di Perpustakaan Pusat Univerisitas Negeri Malang dengan tingkat hubungan sedang. Hal tersebut dapat diketahui, dalam pemenuhan kebutuhan informasi dalam penyelesaian skripsi mahasiswa memanfaatkan koleksi yang tersedia di perpustakaan. Kondisi ketersediaan koleksi perpustakaan yang masih dirasa kurang dilihat dari aspek kemutakhiran dan relevansi membuat sebagian besar mahasiswa memenuhi kebutuhan informasinya melalui internet dan lembaga informasi lain.

\section{SARAN}

Berdasarkan kesimpulan dan hasil analisis penelitian, diharapkan Perpustakaan Pusat UM melibatkan mahasiswa atau perwakilan dari jurusan dalam kegiatan pengadaan koleksi agar dapat diketahui kebutuhan informasi mahasiswa.. Selain itu, diharapkan pengembangan koleksi yang disediakan di Perpustakaan Pusat UM dapat mengikuti perkembangan kurikulum yang berlaku saat ini. Hal tersebut dimaksudkan agar sumber informasi yang tersedia di perpustakaan dapat dimanfaatkan dengan maksimal khususnya dalam kegiatan penyelesaian skripsi mahasiswa. 


\section{DAFTAR RUJUKAN}

Arikunto, Suharsimi. (2010). Prosedur Penelitian: Suatu Pendekatan Praktik. Jakarta: Rineka Cipta.

Almas, H. (2017). MANAJEMEN SISTEM INFORMASI DI PERPUSTAKAAN SMK NEGERI 3 MALANG. BIBLIOTIKA: Jurnal Kajian Perpustakaan Dan Informasi, 1(1), 91-100. https://doi.org/10.17977/um008v1i12017p091

Darmono. ( 2001). Manajemen dan Tata Kerja Perpustakaan Sekolah. Jakarta : Grasindo

Hanafiyah, F. (2018). LITERASI LINTAS KURIKULUM DALAM PEMBELAJARAN BAHASA INDONESIA PADA SEKOLAH MENENGAH KEJURUAN. BIBLIOTIKA : Jurnal Kajian Perpustakaan dan Informasi, 1(2), 4147.

Hasugian, Jonner.2008. Penelusuran Online dan Ketersediaan Sumber Daya Elektronik. (Online). (repository.usu.ac.id /bitstream/hand le/123 456 789/64559/Penelusuran.pdf?sequence=1), diakses pada 13 November 2017

Humairo, Yayang Nst. (2015). Pengaruh Ketersediaan Koleksi Terhadap Pemanfaatan Koleksi Pada Perpustakaan IAIN Sumatera Utara. Skripsi tidak diterbitkan

Istiana, Purwani. (2014).Layanan Perpustakaan. Yogyakarta: Penerbit Ombak

Koto, Indi Ade Fitri. (2007). Identifikasi Kebutuhan Informasi Peneliti dalam Menunjang Kegiatan Penelitian pada Pusat Penelitian Kelapa Sawit Sumatera Utara. Skripsi tidak diterbitkan

71 | BIBLIOTIKA : Jurnal Kajian Perpustakaan dan Informasi 